
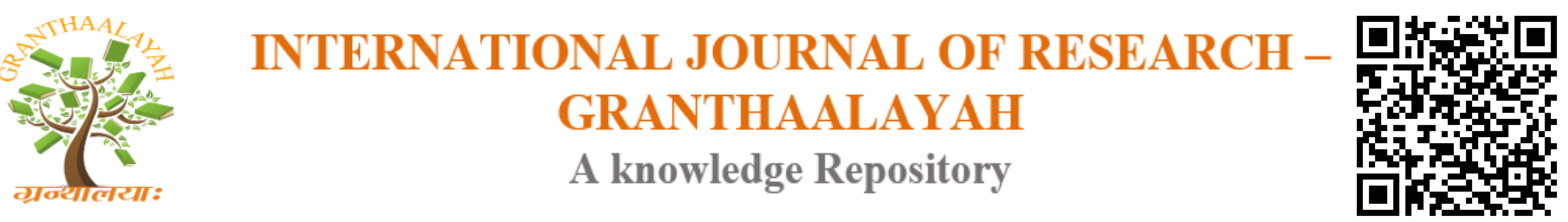

Science

\title{
ELECTROCHEMICAL STUDIES FOR CORROSION INHIBITION OF MILD STEEL BY CHRYSOPHYLLUM ALBIDUM EXTRACT
}

\author{
Akoma Chigozie S. ${ }^{* 1,2}$, Osarolube Eziaku ${ }^{2}$, Abumere O. E. ${ }^{2}$ \\ ${ }^{* 1}$ Department of Physics Electronics, Abia State Polytechnic, Aba, Nigeria \\ ${ }^{2}$ Department of Physics, University of Port Harcourt, Port Harcourt, Nigeria
}

\begin{abstract}
The corrosion behavior of mild steel in carbonated drinks produced by Nigerian Breweries (Fanta, Sprite and Coke) was studied in the presence and absence of an eco-friendly inhibitor, Chrysophyllum albidum using Potentiodynamic polarization technique at $25{ }^{\circ} \mathrm{C}$. Results showed that Chrysophyllum albidum reduced the current density $\left(i_{\text {corr }}\right)$, which in turn means that the corrosion rate was reduced significantly. The inhibition efficiency was found to be $93 \%, 78.6 \%$ and $87.5 \%$ for Fanta, Sprite and Coke respectively. The study also showed that Chrysophyllum albidum functioned as a mixed-type corrosion inhibitor in the three environments studied and therefore presents it as a long-term inhibitor for the corrosion of mild steel.
\end{abstract}

Keywords: Chrysophyllum Albidum; Potentiodynamic Polarization; Corrosion Inhibition; Inhibitor; Carbonated Drinks; Corrosion Rate.

Cite This Article: Akoma Chigozie S., Osarolube Eziaku, and Abumere O. E.. (2018). "ELECTROCHEMICAL STUDIES FOR CORROSION INHIBITION OF MILD STEEL BY CHRYSOPHYLLUM ALBIDUM EXTRACT." International Journal of Research - Granthaalayah, 6(1), 415-420. https://doi.org/10.29121/granthaalayah.v6.i1.2018.1636.

\section{Introduction}

Crown corks of carbonated drinks corrode with time under storage conditions and this can lead to negative impact on the product and consequently, decline in the demand of the product (Akoma et al., 2015). Studies by researchers most times have been centered on aggressive environment (the strong alkaline and the acidic solutions). Corrosion takes place also in the food industries and when the corroded part comes in contact with the food, it could lead to food poisoning. Crown corks of carbonated drinks corrode over time because of the presence of carbon dioxide - an acid gas used in preserving the drinks (Akoma et al., 2015). The crown cork is made of low carbon steel (which makes it suitable to use mild steel as an experimental coupon) mostly electroplated with chromate which serve as a surface finisher and a corrosion inhibitor. The extract of Chrysophyllum albidum fruit was used to inhibit the corrosion of mild steel in carbonated drinks environment using electrochemical studies (potentiodynamic polarization). 
The inability of gravimetric experiments to contain the factors necessary for long-term corrosion experiments provides a gap which needs to be filled by the measurement of fundamental reaction kinetics (Richard, 2014). Electrochemistry experiments, of which potentiodynamic polarization is one, promises to provide a measurement for these. The purpose of potentiodynamic polarization experiments is primarily to enable identification and understanding of the reactions, rate determining processes, and the stability of the passive film. Even if the technique could produce very accurate rate measurements, it would only be good for the pristine surface immersed into the solution for a relatively short time and the precise solution chemistry, temperature, aeration, etc. at the moment of measurement. Gravimetric experiments very rarely exhibit constant rates over time and may not contain such short-term experiments may not contain any of the factors that alter corrosion rates with time of exposure for long term behaviours.

Chrysophyllum albidum is widely distributed in the low land rain forest zones and frequently found in villages (Madubuike and Ogbonnaya, 2003). Often called white star apple, its presence is more felt in the late December and early three months of the year. Their rich sources of natural antioxidants have been established to promote health by acting against oxidative stress related diseases such as; diabetics, cancer and coronary heart diseases (Burits and Bucar, 2002). Many researchers have found out its medicinal values (Adisa, 2000; Idowu et al., 2006; Ajetunmobi and Towolawi, 2014; Adebayo et al., 2010) and have also shown that it contains biologically active substances that include alkaloids, tannin, saponin, phenol and flavonoid (Okoli and Okere, 2010).

This work, therefore considers the anti-corrosive ability of Chrysophyllum albidum on mild steel using potentiodynamic polarization (Electrochemical) studies.

\section{Materials and Method}

\subsection{Materials}

The materials required to carry out this experimental research are mild steel, Chrysophllum albidum fruit sap, silicon emery paper (grade nos 200, 400, 600), digital weighing balance, filter paper, vernier callipers, micrometer screw gauge, desiccators, acetone, ethanol, distilled water, polytetrafluoroethylene (PTFE) rods, polytetrafluoroethylene (PTFE) rods, and V3 studio software.

\subsection{Method}

Test metal samples of mild steel for electrochemical experiment were machined into cylindrical specimens and fixed in polytetrafluoroethylene (PTFE) rods by epoxy resin in such a way that only one surface of area $1 \mathrm{~cm}^{2}$ was left uncovered. The electrodes (cylindrical specimen sample of Mild steel, MS) used were polished with emery papers (from 800 to 1200), rinsed with distilled water, degreased by ethanol, dried in acetone. Electrochemical experiment were conducted in a three electrode corrosion cell using a VERSASTAT 400 complete DC voltammetry and corrosion system with V3 studio software for potentio-dynamic/Galvanostat corrosion system with E-chem software for potentio-dynamic polarization experiments. A 
platinum sheet was used as counter electrode and a saturated calomel electrode (SCE) was used as reference electrode. The latter was connected via a luggins capillary. Potentiodynamic polarization studies were carried out in the potential range $\pm 250 \mathrm{mV}$ versus corrosion potential at a scan rate of $0.5 \mathrm{mVs}^{-1}$ for mild steel. Each test was run in triplicate to verify the reproducibility of the data. All experiments were carried out in freshly prepared solution at constant temperature $25 \pm 1^{\circ} \mathrm{C}$ using a thermostat as reported by Chidiebere et al., 2015 (Chidiebere et al., 2015).

The inhibition efficiency from the potentiodynamic polarization was quantified using the formula (Chidiebere et al., 2015; Osarolube, 2017; Akalezi and Oguzie, 2016; Nnanna et al., 2014, 2010; Akpan and Offiong, 2013).

$$
I E \%=\left(\frac{I_{\operatorname{corr}(b l)}-I_{\operatorname{corr}(i n h)}}{I_{\operatorname{corr}(b l)}}\right) \times 100
$$

Where $\mathrm{I}_{\text {corr(bl) }}$ and $\mathrm{I}_{\text {corr(inh) }}$ represents the corrosion current density in the absence and presence of the inhibitor, respectively (Chidiebere et al, 2015).

\section{Results and Discussions}

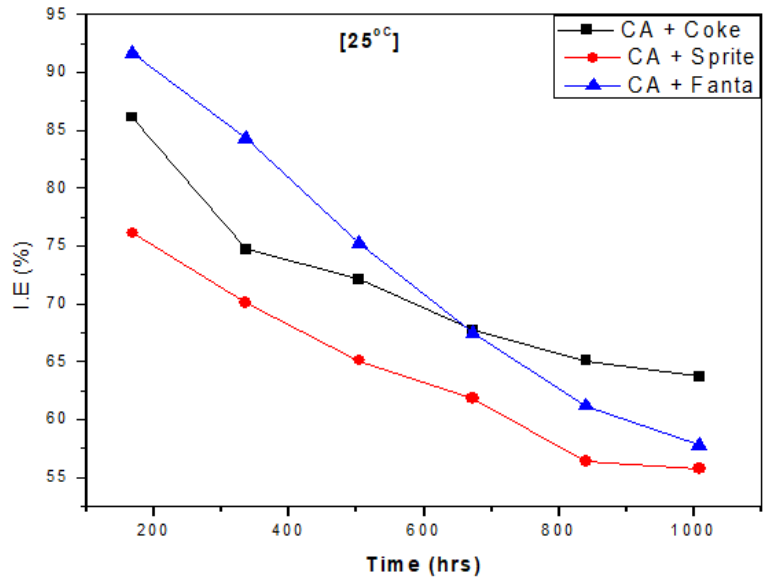

Figure 1: Variation of inhibition efficiency with time for a period of $1008 \mathrm{hrs}$ in the absence and presence of Chrysophyllum albidum in the various corrosive solutions and at $25^{\circ} \mathrm{C}$.

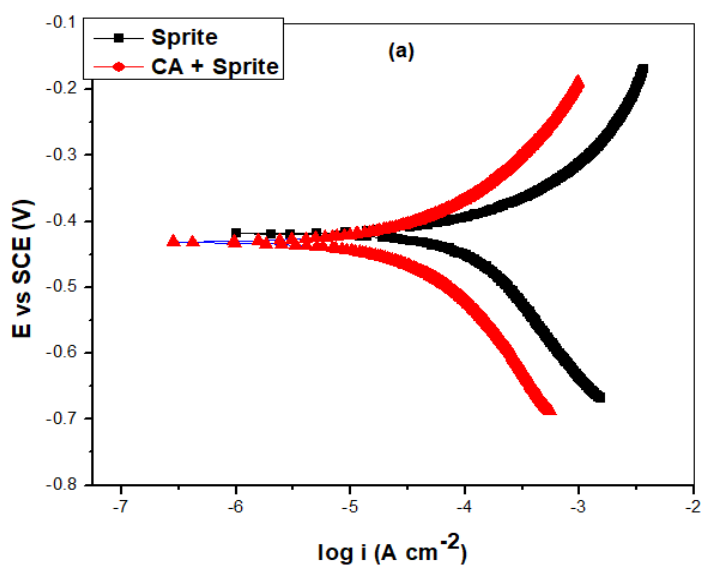

Figure 2: Potentiodynamic polarization curves for mild steel in Sprite in the absence and presence of extracts of Chrysophyllum albidum 


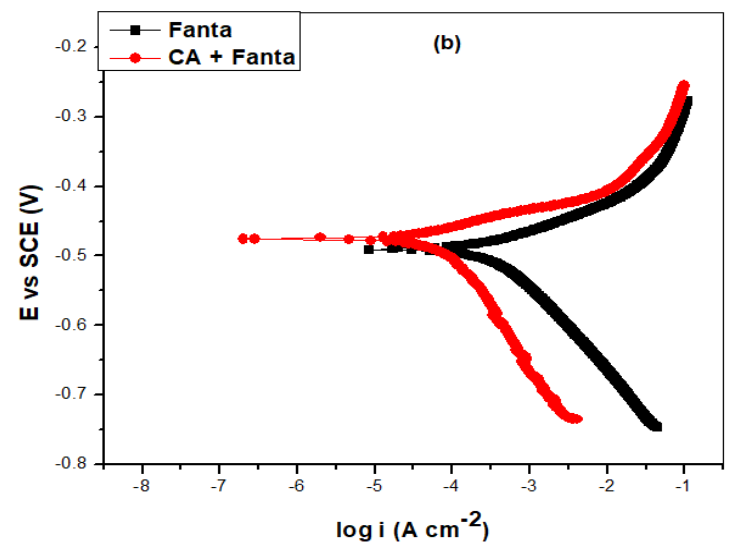

Figure 3: Potentiodynamic polarization curves for mild steel in Fanta in the absence and presence of extracts of Chrysophyllum albidum

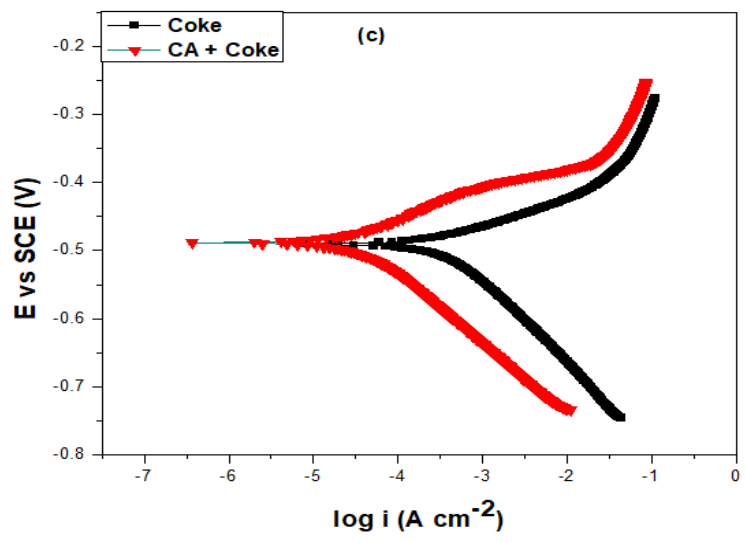

Figure 4: Potentiodynamic polarization curves for mild steel in Coke in the absence and presence of extracts of Chrysophyllum albidum

Figure 1 presents the graph of the inhibition efficiency of Chrysophyllum albidum in the different carbonated drinks at $25^{\circ} \mathrm{C}$ (Akoma et al., 2015). The potentiodynamic polarization experiments performed showed the effect of Chrysophyllum albidum on the anodic dissolution reaction of mild steel and the cathodic hydrogen ion reduction. Potentiodynamic polarization plots for mild steel corrosion in Sprite, Fanta and Coke in the absence and presence of Chrysophyllum albidum are given in Figure 2, 3 and 4 respectively while the potentiodynamic polarization parameters derived from the polarization curves are summarized in table 1. The obtained results reveal that Chrysophyllum albidum modified both the anodic and cathodic reactions, and displaced the corrosion potential $\left(\mathrm{E}_{\text {corr }}\right)$ slightly though not significant, towards cathodic values, especially in Sprite environment, while reducing both the cathodic and anodic current densities as well as the reaction current density ( $\left.i_{\text {corr }}\right)$. The reduction of the current density ( $\left.i_{\text {corr }}\right)$ in the introduction of the inhibitor implied that the inhibitor functioned to reduce the mass loss. Chrysophyllum albidum thus functioned as a mixed-type corrosion inhibitor in the three studied environments. From Table 1 and the graphs, Chrysophyllum albidum caused a decrease in the $\mathrm{i}_{\text {corr }}$ values from higher to lower current values. This occurred in the presence of Chrysophyllum albidum. Also, the $\mathrm{i}_{\text {corr }}$ values reduced considerably on adding Chrysophyllum albidum extract indicating that the extract effectively reduced mild steel corrosion in the test solutions. The electrochemical results are in good agreement with the gravimetric data as reported by Akoma et al. (2015). 
Table 1: Polarization Parameters for Mild Steel in Sprite, Fanta and Coke in the Absence and Presence of Chyrsophyllum albidum $(\mathrm{CA})$ at $25^{\circ} \mathrm{C}$

\begin{tabular}{|c|c|c|c|c|}
\hline System & $\mathrm{E}_{\text {corr }}(\mathrm{mV}$ vs SCE) & $I_{\text {corr }}\left(\mu \mathrm{A} / \mathrm{cm}^{2}\right)$ & IE\% & Surface coverage $(\theta)$ \\
\hline Sprite & -483.3 & 83 & & \\
\hline $\mathrm{CA}+$ Sprite & -488.3 & 18.6 & 78.6 & 0.79 \\
\hline Coke & -470.8 & 87 & & \\
\hline $\mathrm{CA}+$ Coke & -514.8 & 10.4 & 87.5 & 0.88 \\
\hline Fanta & - 488.9 & 79.8 & 03 & 003 \\
\hline $\mathrm{CA}+$ Fanta & -463.7 & 5.6 & 93 & 0.93 \\
\hline
\end{tabular}

\section{Conclusion}

This research was performed on proffering a long-term inhibitor for corrosion of mild steel. Potentiondynamic polarization technique was used in the measurement of corrosion potential and current density of the metals in the presence and absence of the inhibitor. The current density $\left(i_{\text {corr }}\right)$ reduced after exposure in the corrosive media with the inhibitor extract present. By this reduction of current density and current potential, Chrysophyllum albidum can be presented as a long term inhibitor for corrosion of mild steel exposed to carbonated environments.

\section{References}

[1] Abdallah M., Megahed H. E., Radwan M. A., and Abdfattah E. (2012). "Polyethylene glycol compounds as corrosion inhibitors for aluminium in $0.5 \mathrm{M}$ hydrochloric acid solution," Journal of American Science, vol. 8, no. 11, pp. 49-55.

[2] Adebayo A. H., Abolaji A. O., Opata T. K., Adegbenro I. K. (2010). Effects of ethanol on leaf extract of Chrysophyllum albidum G. on biochemical and hematological parameters of albino Wistar rats. African Journal of Biotechnology, vol. 9, No. 14, pages 2145-2150.

[3] Adisa S. A. (2000). Vitamin C, protein and mineral content of African apple (Chrysophyllum albidum) in proceedings of the 18th Annual Conference of NIST. (Eds), pages 141-146.

[4] Ajetunmobi, A. O. and Towolawi, G. A. (2014). Phytochemical Analysis and Antimicrobial Effect of Chrysophillum albidum Leave Extract on Gastrointestinal Tract Pathogenic Bacteria and Fungi in Human. IOSR Journal of Applied Chemistry (IOSR-JAC). Volume 7, Issue 1 Ver. II, pages $1-5$.

[5] Akalezi Chris O., OguzieEmeka E. (2016). Evaluation of anticorrosion properties of Chrysophyllum albidum leaves extract for mild steel protection in acidic media. Int J. IndChem, 7:81-92

[6] Akoma C.S., Osarolube E. , Abumere O. E., Nnanna L. A., John W. O., (2015). Corrosion Inhibition of Crown Corks of Carbonated Drinks Using Chyrsophyllum albidium Extract. Int'1 J. of Engineering Research and Reviews, vol. 3, Issue 4, pp: (67-74). ISSN 2348-697X(Online)

[7] Akpan I. A. and Offiong N. O. (2013). Inhibition of Mild Steel Corrosion in Hydrochloric Acid Solution by Ciprofloxacin Drug. International Journal of Corrosion .http://dx.doi.org/10.1155/2013/301689.

[8] Bhat J. I. and Alva V. (2009). "Corrosion inhibition of aluminium by 2-chloronicotinic acid in $\mathrm{HCl}$ medium," Indian Journal of Chemical Technology, vol. 16, no. 3, pp. 228-233.

[9] Burits M. and Bucar F. (2002). Antioxidant activity of Chrysophyllum albidum essential oil. Phtother Res. Institute of Pharmacognosy, Vol. 14, pages 323-328. 
[10] Chidiebere, M.A,, Emeka E. O., Li L., Ying L., Fuhui W. (2015) Adsorption and corrosion inhibiting effect of riboflavin on Q235 mild steel corrosion in acidic environments, Materials Chemistry and PhysicsVol. 156, pages 95-104.

[11] Osarolube, E. (2017). A Potential Corrosion Inhibitor for Acid Corrosion of Mild Steel. Materials Sciences and Applications, 8, 476-483. https://doi.org/10.4236/msa.2017.86032

[12] Idowu T. O., Onawunmi G. O., Ogundaini A. O., Adesanya S. A. (2003). Antimicrobial constituents of Chrysophyllum albidum seed cotyledons. Nig J. Nat Prod. And Med. Vol. 7, pages 33-36.

[13] Madubuike F. N., Ogbonnaya O. (2003). The Potential Use of White Star Apple Seed (C .albidum) and Physic Nut (jatrophacurcas) as Feed Ingredients for Rats. J. Fac. Agric. Vet. Med., Vol. 1, pages 97-105.

[14] Mejeha I. M., Uroh A. A., Okeoma K. B., Alozie G. A. (2010). The inhibitive effects of Solanum melongena L. Leaf extract on the corrosion of aluminium in tetraoxosulphate (VI) acid. Afr. J. Pure Appl. Chem., 4(8): 158-165

[15] Nnanna L. A., John W. O., Nwadiuko O. (2014). Corrosion Inhibition Study of Aluminum AA3003 in Alkaline Medium by Palisota hirsute Extract. International Journal of Engineering Research and Reviews, Vol. 2, Issue 4, pp: (113-118).

[16] Nnanna L. A., Onwuagba B. N., Mejeha I. M., Okeoma K. B. (2010). Inhibition effects of some plant extracts on the acid corrosion of aluminium alloy. Afr. J. Pure Appl. Chem., 4(1): 11-16.

[17] Oguzie E.E. (2008). Evaluation of some inhibitive effect of some plant extracts on the acid corrosion of mild steel. Corros. Sci., 50: 2993- 2998.

[18] Okoli B. J., Okere O. S. (2010). Antimicrobial Activity of the Phytochemical Constituents of Chrysophyllum albidum G.Don_Holl. (African Star apple) Plant. Journal of Research in National Development, vol. 8, issue 1, retrieved from http://www.transcampus.org/JORINDV8Jun2010/JournalsV8NO1Jun201035.html

[19] Richard E. R. (2014). How reliable is the potentiodynamic polarization in predicting the corrosion behavior? Retrieved on 05/01/2018 from https://www.researchgate.net/post/How_reliable_is_the_potentiodynamic_polarization_in_predict ing_the_corrosion_behavior.

\footnotetext{
*Corresponding author.

E-mail address: chigozieakoma@yahoo.com
} 